LATVIAN JOURNAL OF PHYSICS AND TECHNICAL SCIENCES

2016, N 1

DOI: $10.1515 /$ pts-2016-0004

\title{
RESEARCHING AND DESIGNING PHOTOVOLTAIC MICROSYSTEMS
}

\author{
D. Hilse ${ }^{1}$, J. Kapała ${ }^{1}$, K. Sztymelski², N. Zeltins ${ }^{3}$, J. Ekmanis ${ }^{3}$ \\ ${ }^{1}$ University of Bielsko-Biala, Faculty of Materials, Civil and Environmental \\ Engineering, Institute of Environmental Protection and Engineering \\ ul. Willowa 2, 43-309 Bielsko-Biala, POLAND \\ Email: biuro@hilkap.eu \\ ${ }^{2}$ Silesian University of Technology, Faculty of Electrical Engineering, \\ Institute of Industrial Electrical Engineering and Computer Science \\ ul. Akademicka 10, 44-100 Gliwice, POLAND \\ ${ }^{3}$ Latvian Member Committee of WEC \\ Akademijas laukums 1-1, LV-1050, Riga, LATVIA
}

\begin{abstract}
Research on the photovoltaic module efficiency in the south of Poland was conducted in 2009 in Stryszawa and afterwards in 2012 in Zabrze and Stryszawa. The research involved taking measurements of electric energy produced by systems of various power and technical solutions. The efficiency of PV modules was compared to the intensity of solar radiation in the locations under consideration and, thus, the efficiency of converting solar energy into electricity was determined. The research results facilitated designing and mounting of forty PV microsystems in Zabrze in 2014 (power from $2000 \mathrm{Wp}$ to $3000 \mathrm{Wp}$ ). To the satisfaction of their users, they operate without failure.
\end{abstract}

Keywords: converting solar energy into electricity, photovoltaic, PV modules and systems, solar radiation.

\section{INTRODUCTION}

Poland does not belong to countries characterised by the highest potential of solar energy, which is $850 \div 1300 \mathrm{kWh} / \mathrm{m}^{2}$ year, whereas in equatorial countries, South America and Africa it exceeds $2200 \mathrm{kWh} / \mathrm{m}^{2}{ }_{*}$ year [1]. Nevertheless, the possessed potential is sufficient to cover $1 / 3$ of the need of energy in Poland [2].

In practice, making use of the possessed potential of solar energy should not pose major technical problems, in case photovoltaic cells in the form of photovoltaic modules are applied. They are indispensable for designing and mounting of microsystems producing low-voltage current, which is used:

- directly, e.g. to illuminate squares, streets, real estates, or places which are difficult to connect to mains power supply;

- $\quad$ after it is converted into $230 \mathrm{~V}$ current.

In the second case, the installation can be off-grid or on grid. 
Off-grid systems are used as independent (in case of objects without the external power grid) or as emergency (when frequent power outages occur). It comprises: photovoltaic modules, batteries, charge regulators, transducers.

On-grid systems enable "mixing" electric energy produced by photovoltaic modules and electricity provided by the external power grid. They do not require using batteries, due to the fact that the excess of produced energy can be resold to the distributor.

Designing and constructing photovoltaic systems, off-grid microsystems in particular, should be based on precise determination of solar radiation at certain times in a certain area, with simultaneous evaluation of installed photovoltaic module efficiency.

In particular, it concerns mountainous areas, where the intensity of solar radiation changes significantly even during one day, depending on the topography [3].

The paper presents the results of the research on the efficiency of several photovoltaic systems in two locations in Poland:

- Zabrze (city at an altitude of 239 meters, geographical coordinates $\left.50^{\circ} 19^{\prime} 29^{\prime \prime} \mathrm{N}, 18^{\circ} 47^{\prime} 8^{\prime \prime} \mathrm{E}\right)$;

- Stryszawa (village at an altitude of 591 meters, geographical coordinates $\left.49^{\circ} 40^{\prime} 54^{\prime \prime} \mathrm{N}, 19^{\circ} 29^{\prime} 0^{\prime \prime} \mathrm{E}\right)$.

They were used for designing and mounting of numerous PV microsystems (on-grid), inter alia in the territory of Zabrze.

\section{EXPERIMENTAL SYSTEMS, METHODS AND RESEARCH RESULTS}

The first series of research (in 2009) consisted in mounting three PV systems in the experimental station in Stryszawa, which are the following [3]:

1. a system comprising three photovoltaic modules with power of $3 \times 190$ $\mathrm{Wp}=570 \mathrm{Wp}$ and total surface of $5.2 \mathrm{~m}^{2}$; modules were mounted on a rotating frame (tracking the movement of the Sun), in an open space;

2. a system comprising two photovoltaic modules with power of $2 \times 180 \mathrm{Wp}$ $=360 \mathrm{Wp}$ and total surface of $3.4 \mathrm{~m}^{2}$; modules were mounted on a stationary frame, in an open space;

3. a system comprising one photovoltaic module with power of $200 \mathrm{Wp}$ and total surface of 1-9 $\mathrm{m}^{2}$; the module was mounted on the southern wall of a residential building.

Experimental systems contain the following elements:

- $\quad$ photovoltaic modules;

- battery charge regulators;

- batteries (accumulating direct current 12 or $24 \mathrm{~V}$ );

- transducers - inverters, changing direct current into alternating current $230 \mathrm{~V}$;

- meters of energy units produced and transmitted to consumption.

The experimental station performed a function of an off-grid system, in which 
the current was used directly by the producer, and the produced excess was used by the engine working uselessly at an idle speed.

The third system is able to operate on direct current (24 V), with illumination and supplying buffers of central heating as the aims of generated electricity.

The amount of energy generated by the systems described above was measured using typical meters, which were read at the end of every month in 2009 . The obtained results were compared to the values of intensity of solar radiation in Żywiec (the distance from the experimental station is less than $20 \mathrm{~km}$ ), taken from the Silesian Air Monitoring database [5].

The results of research conducted in 2009 are summarised in Tables 1-3 [3].

Table 1

The Efficiency of FV Modules at the Experimental Station in Stryszawa in 2009

\begin{tabular}{|l|c|c|c|}
\hline \multirow{2}{*}{ Month } & \multicolumn{3}{|c|}{ Electricity production, $\mathbf{k W h} / \mathbf{m}^{\mathbf{2}}$} \\
\cline { 2 - 4 } & System 1 & System 2 & System 3 \\
\hline I & 24.4 & 12.6 & 5.9 \\
\hline II & 27.6 & 14.3 & 6.8 \\
\hline III & 49.9 & 26.2 & 12.4 \\
\hline IV & 114.4 & 56.1 & 28.3 \\
\hline V & 102.4 & 48.6 & 25.1 \\
\hline VI & 82.2 & 40.5 & 20.7 \\
\hline VII & 99.3 & 45.6 & 23.4 \\
\hline VIII & 111.3 & 51.0 & 25.7 \\
\hline IX & 80.6 & 39.4 & 19.8 \\
\hline X & 41.6 & 20.4 & 9.9 \\
\hline XI & 37,4 & 19.7 & 9.3 \\
\hline XII & 12,5 & 6.1 & 2.8 \\
\hline 2009 & 783,6 & 380.5 & 190.1 \\
\hline
\end{tabular}

The Efficiency of FV Modules in Stryszawa Compared to the Intensity of Solar Radiation

\begin{tabular}{|c|c|c|c|c|}
\hline \multirow[t]{2}{*}{ Month } & \multirow{2}{*}{$\begin{array}{l}\text { Intensity of solar } \\
\text { radiation, } \mathrm{kWh} / \\
\mathbf{m}^{2}{ }_{*} \text { month }\end{array}$} & \multicolumn{3}{|c|}{ Electricity production, $\mathrm{kWh} / \mathrm{m}^{2}{ }_{*}$ month } \\
\hline & & System 1 & System 2 & System 3 \\
\hline I & 20.42 & 4.7 & 3.7 & 3.1 \\
\hline II & 20.40 & 5.3 & 4.2 & 3.6 \\
\hline III & 42.96 & 9.6 & 7.7 & 6.5 \\
\hline IV & 133.15 & 22.0 & 16.5 & 14.9 \\
\hline $\mathrm{V}$ & 124.80 & 19.7 & 14.3 & 13.2 \\
\hline VI & 102.24 & 15.8 & 11.9 & 10.9 \\
\hline VII & 151.27 & 19.1 & 13.4 & 12.3 \\
\hline VIII & 126.19 & 21.4 & 15.0 & 13.5 \\
\hline IX & 86.76 & 15.5 & 11.6 & 10.4 \\
\hline $\mathrm{X}$ & 38.02 & 8.0 & 6.0 & 5.2 \\
\hline XI & 28.77 & 7.2 & 5.8 & 4.9 \\
\hline XII & 15.10 & 2.4 & 1.8 & 1.5 \\
\hline 2009 & 890.08 & 153.4 & 111.9 & 100.0 \\
\hline
\end{tabular}


The Efficiency of Converting Solar Energy into Electricity at the Experimental Station in Stryszawa

\begin{tabular}{|l|c|c|c|c|}
\hline \multirow{2}{*}{ Month } & \multicolumn{3}{|c|}{ Efficiency of energy conversion, \% } & $\begin{array}{c}\text { Average air } \\
\text { temperature, C } \\
\text { (over the period } \\
\text { 1971-2000) }\end{array}$ \\
\cline { 2 - 4 } & System 1 & System 2 & System 3 & -1.7 \\
\hline I & 23.02 & 18.12 & 15.18 & -2.3 \\
\hline II & 26.00 & 20.59 & 17.65 & 4.9 \\
\hline III & 22.35 & 17.92 & 15.13 & 8.0 \\
\hline IV & 16.52 & 12.39 & 11.19 & 12.4 \\
\hline V & 15.80 & 11.46 & 10.58 & 16.2 \\
\hline VI & 15.45 & 11.64 & 10.66 & 19.2 \\
\hline VII & 12.65 & 8.86 & 8.13 & 17.1 \\
\hline VIII & 16.96 & 11.89 & 10.70 & 8.9 \\
\hline IX & 17.87 & 13.37 & 12.00 & 4.4 \\
\hline X & 21.04 & 15.78 & 13.68 & 0.1 \\
\hline XI & 25.03 & 20.16 & 17.03 & \\
\hline XII & 15.89 & 11.92 & 9.93 & 11.23 \\
\hline 2009 & 17.23 & 12.57 & & \\
\hline
\end{tabular}

From the conducted research, it can be inferred that rotating modules have the highest efficiency, making use of the sun's rays during the whole cycle.

In mountain conditions of Beskid Żywiecki, in Stryszawa to be more specific, they can produce more than $150 \mathrm{kWh} / \mathrm{m}^{2}{ }_{*}$ year. The efficiency of stationary modules mounted in open spaces (or on roofs of buildings) is approximately $25 \%$ lower. The same modules mounted on a façade of a building have $35 \%$ lower efficiency.

Calculated efficiency of converting solar energy into electricity is provided in Table 3. Among others, this factor depends on the temperature of surrounding air. In this case, the highest efficiency, exceeding $17 \%$ annually, was noted in case of rotating modules, reaching the highest values (up to $26 \%$ ) in the winter season.

The above data indicate that as far as FV systems are concerned, the conditions in Stryszawa village are moderately favourable to produce electricity.

The second series of research (in 2012) on the PV system was conducted in Stryszawa as well as in Zabrze.

In Stryszawa, the measurements of the rotating system, already discussed above, were continued. In Zabrze, on the other hand, a stationary system was mounted on a flat roof of a residential building, equipped with four modules with power of $4 \times 250 \mathrm{Wp}=1000 \mathrm{Wp}$ and total surface of $6.4 \mathrm{~m}^{2}$. Both the above-mentioned systems are off-grid type.

The way of conducting measurements was identical to the first series.

During the research, the efficiency of PV systems in relation to the intensity of solar radiation was determined. The measurement results are summarised in Table 4 (rotating module in Stryszawa) and in Table 5 (stationary module in Zabrze). In this part, for the purpose of comparison, PVGIS European Union, 2001-2012 was used [6]. 
The results of measurements and conclusions drawn from the second series of the research confirm previous findings, namely:

a) taking into consideration the conditions in southern Poland, it is sensible to use solar energy in order to produce electricity with the aid of photovoltaic microsystems;

b) rotating systems are more efficient than stationary photovoltaic systems.

Table 4

The Efficiency of a Rotating Module in Stryszawa in Relation to the Intensity of Solar Radiation in 2012

\begin{tabular}{|l|c|c|}
\hline Month & $\begin{array}{c}\text { Intensity of solar radiation, } \\
\mathrm{kWh} / \mathrm{m}^{2}{ } \text { month }\end{array}$ & $\begin{array}{c}\text { Electricity production, } \mathrm{kWh} / \\
\mathrm{m}^{2}{ }{ }^{\text {month }}\end{array}$ \\
\hline I & 34.2 & 5.45 \\
\hline II & 46.2 & 7.35 \\
\hline III & 99.0 & 15.17 \\
\hline IV & 135.0 & 20.40 \\
\hline V & 141.0 & 21.40 \\
\hline VI & 135.0 & 20.40 \\
\hline VII & 150.0 & 22.30 \\
\hline VIII & 145.0 & 21.93 \\
\hline IX & 105.0 & 16.25 \\
\hline X & 77.3 & 12.20 \\
\hline XI & 42.0 & 6.80 \\
\hline XII & 30.2 & 4.42 \\
\hline 2012 & 1140.0 & 174.0 \\
\hline
\end{tabular}

Table 5

The Efficiency of a Stationary Module in Zabrze in Relation to the Intensity of Solar Radiation in 2012

\begin{tabular}{|l|c|c|}
\hline Month & $\begin{array}{c}\text { Intensity of solar radiation, } \\
\mathrm{kWh} / \mathrm{m}^{2}{ }_{*} \text { month }\end{array}$ & $\begin{array}{c}\text { Electricity production, } \mathrm{kWh} / \\
\mathrm{m}^{2}{ }_{*} \text { month }\end{array}$ \\
\hline I & 33.1 & 4.42 \\
\hline II & 50.9 & 6,63 \\
\hline III & 110.0 & 13.90 \\
\hline IV & 148.0 & 17.97 \\
\hline V & 161.0 & 19.06 \\
\hline VI & 158.0 & 18.28 \\
\hline VII & 165.0 & 19.06 \\
\hline VIII & 158.0 & 18.28 \\
\hline IX & 117.0 & 14.11 \\
\hline X & 84.5 & 10.47 \\
\hline XI & 42.5 & 5.49 \\
\hline XII & 31.0 & 4.08 \\
\hline 2012 & 1260.0 & 151.72 \\
\hline
\end{tabular}




\section{DESIGNING AND CONSTRUCTING PHOTOVOLTAIC MICROSYSTEMS IN ZABRZE}

The awareness of the issues discussed above and research results facilitated designing and constructing 40 photovoltaic microsystems in Zabrze in 2014, each with power from $2000 \mathrm{Wp}$ to $3000 \mathrm{Wp}$. The total cost of one system (design, materials and components, mounting, commissioning, handling formal and legal matters, and others) was from 12500 PLN to 15000 PLN (where $1 €=$ approximately 4.1 PLN). The microsystems were mounted on private residential buildings, with the subsidy of the Municipal Office of Zabrze - up to 12000 PLN of financial support for each system [4].

At the request of the majority of investors, on-grid type systems were mounted, which resulted in an additional reduction of investment costs, due to the elimination of expensive and problematic batteries.

An example of an implemented investment is a microsystem consisting of $8 \mathrm{PV}$ panels, polycrystalline, with power of $8 \times 250 \mathrm{Wp}=2000 \mathrm{Wp}$. They are connected in a string. One-phase STECA Coolcept 1800 inverter was used as an on-grid inverter, with maximum power of $1.84 \mathrm{~kW}$. It enables the over-dimensioning of DC system up to $30 \%$, which enhances the operation of MPPT system and higher efficiency of the system in case of a partly clouded sky and an unbeneficial position of the sun.

PV panels were mounted on a flat roof, in one row, at a fixed angle of $32^{\circ}$ and approximately $200^{\circ} \mathrm{SSW}$.

PV systems are connected into the public grid by energy supplies (in this case TAURON Polska Energia). Electricity gross meters as well as bidirectional meters are provided and installed by TAURON, at the expense of the company. All the activities, including preparing an appropriate location necessary for placing meters, with protective seals before and behind the meter, designing and drawing diagrams of installations, are performed by a person with proper qualifications.

In order to minimise losses, as for DC, connections were made using a dedicated silver plated wire with cross section of $6 \mathrm{~mm}^{2}$, containing a single conductor, with insulation characterised by higher resistance against UV radiation.

All the connections were made using dedicated, tight MC4 connectors. The electrical wiring was installed in an electrical conduit, so that different elements of the DC system could be gathered in one place. Furthermore, placing wires in electrical conduits prevents arising unbeneficial static magnetic fields. As for AC, all the connections were made using YLgYżo cable $\left(3 \times 2.5 \mathrm{~mm}^{2}\right)$.

The heart of the on-grid type PV system is an on-grid inverter. This device cannot be off-grid (disconnected from the grid). The choice of the inverter was not accidental. Apart from all possible DC and AC protectors, this inverter is equipped with a built-in web server, the function of registering the amount of generated electricity: daily, monthly or annually, every 30 days, months or years. It also has a built-in network interface card and RS485 interface, allowing reading and storing data. Its expanded menu enables to exert influence on the frequency, PF coefficient and reactive power generation. The output active power can be reduced manually. 
The above-mentioned options make it possible to perform a thorough analysis of a PV system.

Electricity meters installed by TAURON, the so-called "intelligent meters", are provided with a transmission service. On a website, to which the owner of the system has an access, it is possible to monitor the amount of used, generated and produced gross energy with accuracy of $1 \mathrm{~h}$. The data can be downloaded as an excel file.

An example of visual presentation of the amount of generated and used energy, for a PV microsystem with power of $2 \mathrm{kWp}$ - on-grid, is shown in Fig. 1.
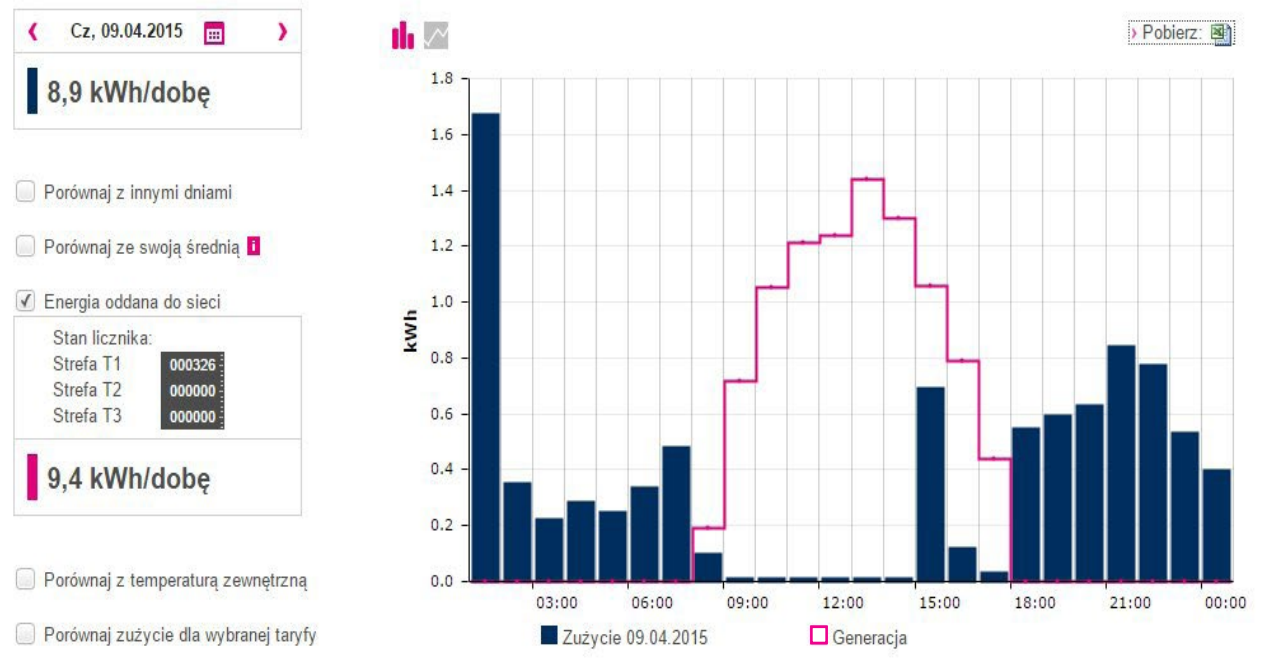

Fig.1. Visual presentation of energy use and generation.

\section{CONCLUSIONS}

The conducted research and analyses indicate that as far as electricity production using PV systems is concerned, conditions in southern Poland are moderately favourable. In this region, average annual electricity production in this kind of systems is $110 \div 175 \mathrm{kWh} / \mathrm{m}^{2}$, when the intensity of solar radiation is $890 \div 1260 \mathrm{kWh} /$ $\mathrm{m}^{2}$. PV systems with the highest efficiency are the ones equipped with modules on rotating frames, whereas systems on stationary frames prove to have $20 \div 25 \%$ lower efficiency. The highest monthly efficiency of converting solar energy into electricity can be noted in winter months (XII, I, II).

In 2014, based on the research results obtained so far, 40 micro on-grid type photovoltaic systems with power from $2000 \mathrm{Wp}$ to $3000 \mathrm{Wp}$ were designed and mounted in Zabrze. One of them has been thoroughly discussed above. The results of their operation, after almost a year of operating, are very encouraging. This has been followed by a rapidly increased interest in mounting further PV microsystems across the country. 


\section{REFERENCES}

4. Martyn, D. (1995). Klimaty kuli ziemskiej. Wydawnictwo Naukowe PWN, Warszawa.

5. Hilse, D. and Kapała J. (2011). Fotowoltaika-elektryfikacja bezdrutowa. Fotowoltaika $1,16-17$.

6. Hilse, D. and Kapała J. (2013). Badania wydajności modułów fotowoltaicznych. Inżynieria Ekologiczna (Ecological Engineering) 33, 41-48.

7. Hilse, D. and Kapała J. (2014). Lampy oświetleniowe hybrydowe. Fotowoltaika 4, 1011.

8. Śląski Monitoring Powietrza. Available at/http://stacje.katowice.pios.gov.pl/iseo/

9. PVGIS Europäische Union, 2001-2012. Available at http://re.jrc.ec.europa.eu/pvgis/ apps4/pvest.php?lang=de\&map=europe

\section{FOTOELEMENTU MIKROSISTĒMU PĒTIJJUMI UN PROJEKTĒŠANA}

D. Hilse, J. Kapała, K. Sztymelski, N. Zeltiņš. J. Ekmanis

K opsavilkum s

Saules moduḷu efektivitātes pētījumi tika veikti Polijas dienvidos 2009. gadā Stryszawā un 2012. gadā Zabrzē un Stryszawā. Pētījuma ietvaros tika veikti sistēmu saražotās elektroenerǵijas mērījumi dažādos režīmos un pie dažādiem tehniskajiem risinājumiem. PV moduḷu efektivitāte tika salīdzināta pie dažādas saules starojuma intensitātes, dažādās vietās un dažāda elektroenerğijas pieprasījuma. Pētījuma rezultāti veicināja četrdesmit PV mikrosistēmu, ar jaudu no 2000 līdz 3000 Wp, projektēšanu un montāžu Zabržē 2014. gadā. Šīs sistēmas apmierināja to lietotājus, jo tās darbojas bez atteices.

29.07.2015. 